\title{
Microlending in India: An Equal Access Possibility
}

\author{
Allison V. Thompkins ${ }^{1}$ \\ ${ }^{1}$ Mathematica Policy Research, 955 Massachusetts Avenue, Suite 801, Cambridge, MA, USA. \\ Correspondence: Allison V. Thompkins, Mathematica Policy Research, 955 Massachusetts Avenue, Suite 801, \\ Cambridge, MA, USA.
}

Received: December 7, 2014

Accepted: January 5, 2015

Available online: January 21, 2015

doi:10.11114/aef.v2i1.640

URL: http://dx.doi.org/10.11114/aef.v2i1.640

\begin{abstract}
People with disabilities are disproportionately represented among the poorest of the poor in developing countries. An increasingly common method of combating poverty in developing countries, microlending, has been largely unavailable to those with disabilities. This paper reports on one of the first programs in India to provide the disabled access to microlending. I evaluate the impact of this program by comparing people with disabilities to their non-disabled siblings in treatment and control villages. The estimates suggest that the program led to increased borrowing and educational attainment while having no impact on labor market participation among the disabled.
\end{abstract}

Keywords: Microlending, employment, education, disability, India, development economics

JEL Codes: I25, O15, J14

\section{Introduction}

Interest in providing microloans to people with disabilities in developing countries as a means of diminishing poverty and isolation among this group has grown in recent years. In developing countries, people with disabilities are disproportionately represented among the poorest of the poor, are more prone to severe and prolonged poverty and are "among the most excluded" (Jeffrey and Singal, 2009). Among those with the least education in developing countries, disabled workers earn roughly 33 percent of comparable non-disabled workers (International Labour Office, 2006). The Economic and Social Commission for Asia and the Pacific notes that "persons with disabilities... remain disproportionately undereducated, untrained, unemployed, underemployed and poor." Thus, as DFID writes, "given the high proportion of people with disabilities among the poor, it is unlikely that these targets [international targets of poverty eradication etc.] can be properly achieved without specific efforts to tackle disability" (DFID, 2000).

This paper examines the impacts of the Indira Kranthi Patham program for people with disabilities (IKP) in Andhra Pradesh, India. In 2002, Indira Kranthi Patham, a national program in Andhra Pradesh, launched its disability interventions. Between 2002 and 2004, more than 23,500 self help groups for the disabled were started with over 240,000 members. During this time, over 69,000 people with disabilities secured microloans. Customarily, self help groups are comprised of poor women and are formed at the village level; the purpose of self help groups is to alleviate the poverty of, and to empower, women by providing access to microloans and education on social issues.

The goals of the IKP program were to enhance the economic livelihood of the disabled, to sensitize the community for the inclusion of people with disabilities, and to mainstream disability issues into public policy. This program signaled a change in the approach to disability and microlending programs. Prior to IKP, two other programs in India provided microlending to people with disabilities. The National Handicapped Finance and Development Corporation provided microloans to 19,643 people with disabilities between 1997 and 2005 and the Micro-Finance Scheme dispersed loans to 1,365 people with disabilities between 1997 and 2003.

The identification strategy in this paper uses the fact that exposure to IKP varied by village of residence and disability status. Specific villages were selected to receive the program. This creates the second level of comparison between treatment villages and control villages. The first level of difference is within each village. In treatment villages, only those with disabilities were intended to participate in the program. The non-disabled siblings of people with disabilities were not supposed to receive treatment in treatment villages. In control villages, neither people with disabilities nor their non-disabled siblings were targeted to receive treatment. A priori, non-disabled siblings are assumed to have better outcomes than their disabled counterparts in the absence of the intervention. Therefore, the program should have 
reduced the difference in outcomes between those with disabilities and their non-disabled siblings in treatment villages relative to the same difference in control villages. I use a difference-in-differences estimator that controls for the variation of outcomes across disability status and village of residence. The combination of these two variables is treated as exogenous.

The question of whether participation in microlending improves outcomes is a basic concern for development economists. Although a large body of literature on the impacts of microlending exists, economists do not agree on the efficacy of microlending to lift poor people out of poverty. A number of studies find that microlending leads to positive impacts (Copestake, Bhalotra, \& Johnson, 2001; Pitt \& Khandker, 1998; Tedeschi, 2008). Others find mixed results (Banerjee, Duflo, Glennerster, \& Kinnan, 2010; Copestake, Dawson, Fanning, McKay, \& Wright-Revolledo, 2005). And other studies find that microlending has no impact on participants (Coleman, 1999; MkNelly \& Lippold, 1998; Morduch, 1998). To my knowledge, one paper, Mont and Sen (2009) evaluates microlending to the disabled. They analyze the Indira Krathi Patham program evaluated in the present paper. They find positive effects of microlending to the disabled but do not employ econometric techniques to address identification issues.

The data constructed for this analysis suffers from two potential sources of bias. First, treatment was non-randomly assigned to villages, resulting in an imbalance in the characteristics of people with disabilities in treatment villages and the characteristics of people with disabilities in control villages. To remedy the absence of random assignment, I include non-disabled siblings as a control. The use of non-disabled siblings as a control will mitigate bias from non-random assignment as long as the difference in potential outcomes between those with disabilities and non-disabled siblings is independent of treatment status. Second, some people with disabilities in control villages received treatment, leading to two-sided non-compliance. This bias is resolved by using a treatment village indicator variable as an instrument for individual treatment status.

\section{Background}

\subsection{Disability in India}

This section presents a brief overview of the status of people with disabilities in India. It draws extensively from Jeffrey and Singal (2009) and The World Bank (2007).

Disability in India is often viewed as divine punishment which complicates the delivery of social services. In 2002, 40 percent of people residing in Andhra Pradesh believed disability to be a punishment or curse by God. In rural India, 50 percent of people believe children with mental illness or intellectual disabilities cannot attend school. The same survey reveals that more than 50 percent of people feel that the disabled should not be allowed to participate in certain celebrations and that disabled people cannot be successfully employed. Such perceptions are held by both the disabled and the non-disabled and account for much of the social isolation experienced by those with disabilities.

Partially due to these perceptions of disability, reliable measures of disability prevalence in India are nonexistent as many with disabilities do not identify themselves as disabled. Additionally, the definition of disability varies from survey to survey causing some to be identified as disabled in certain surveys but identified as non-disabled in other surveys. This results in disability prevalence rates ranging from a low of 1.8 percent to a high of 6 percent.

Since prevailing attitudes in India suggest that people with disabilities cannot attend school, disabled people in India have limited interaction with educational institutions. Educational attainment, school enrollment, and literacy rates of the disabled are lower than their non-disabled counterparts. In 2005, children with disabilities had an out-of-school rate more than five times higher than non-disabled children and 52 percent of the disabled in India were illiterate compared to 35 percent of the non-disabled (The World Bank, 2007). This translates into fewer opportunities to engage in income-generating activities. The disabled have substantially lower employment rates than the non-disabled. Disabled men have an employment rate 14 percent lower than non-disabled men. (Note 1)

A natural consequence of the reduced educational and labor market opportunities afforded to those with disabilities and the stigma associated with disability is the tight link between disability and poverty. This phenomenon is particularly acute in rural India where poverty rates are more than double urban poverty rates and disability rates are higher. Approximately 8.6 percent of rural households have a disabled member compared to 6.1 percent of urban households. Households with disabled members have lower rates of asset ownership and are significantly less likely to eat three meals per day.

\subsection{Indira Kranthi Patham Program for People with Disabilities}

Indira Kranthi Patham helps poor people form self help groups (SHGs) and provides health services and training in capacity building. Indira Kranthi Patham is known for its outreach to people with disabilities in Andhra Pradesh.

In 2002, Indira Kranthi Patham expanded and formalized its outreach by establishing the Indira Kranthi Patham disability interventions (IKP), which offered people with disabilities the opportunity to participate in SHGs and to 
secure microloans. To qualify for participation, a person must live in a village covered by the program, meet poverty standards, be between the ages of 5 and 50 years old, and have a disability of 40 percent severity or above. The severity of each person's disability was determined in one of two ways. A person either self-reported his functional limitations or was evaluated at a disability certification camp and given a disability certificate indicating severity of disability.

The IKP program was introduced to villages in 162 mandals throughout Andhra Pradesh. (Note 2) The 162 mandals were assigned to treatment based on the number of people with disabilities residing in the mandal, the interest shown by residents with disabilities in forming SHGs and the extent of economic disadvantage in the mandal. Not all mandals received the same treatment. 78 mandals received the pilot version of the IKP program, which was the most intensive version of the program. The remaining mandals received either the non-intensive version of IKP or received the IKP program through non-governmental organizations that partnered with IKP. Villages in the remaining mandals in Andhra Pradesh were not assigned to treatment and comprise the control group. (Note 3) All villages within each chosen mandal were supposed to receive treatment. However, the availability of IKP staff to lead SHGs and the availability of benefits determined whether a village assigned to treatment actually received treatment. The World Bank reports that "in mostly all villages of the [selected] mandals" SHGs were established and functioning as of August 2008 (ORG Centre for Social Research, 2008).

Once the mandals were chosen, community development workers identified and recruited people with disabilities from each village to join SHGs. Village members compiled a list of people with functional limitations in the village. IKP staff identified those on the list below the poverty line for possible inclusion in SHGs. Once possible participants were identified, IKP staff recruited those identified. However, recruitment was not a necessary condition for participation.

The program was intended to address unmet needs of the disabled. SHGs were designed to meet a minimum of four times per month for the following reasons: to provide members the opportunity to meet with group leaders and other group members, to provide the disabled the opportunity to go into public and to "sensitize the community [of rural India] for [the] inclusion" of people with disabilities (ORG Centre for Social Research, 2008). SHG members were required to create an individual business plan, to save a minimum of 20 rupees per week and to secure loans. These loans were intended to be controlled by the disabled person and were to be used for productive purposes so that SHG members could improve their economic standing and learn financial independence. SHG members were supposed to learn about government programs that benefit the poor and the disabled to heighten awareness among the disabled about disability-centered government programs (The World Bank, 2007).

\section{Data and Descriptive Statistics}

\subsection{IKP Data}

The data for this analysis comes from a household survey conducted in the summer of 2008. People with disabilities in 12 mandals were selected to be surveyed. The sample design randomly selected mandals from treatment and control categories. However, oversampling in treatment mandals resulted in three-fourths of the sample residing in treatment villages and one-fourth residing in control villages. Eight villages from each mandal were chosen using systematic random sampling.

20 people with disabilities from each village were selected for inclusion in the sample. (Note 4) In treatment villages, 10 people chosen randomly from SHG participants and 10 people chosen randomly from SHGs non-participants comprise the survey respondents. (Note 5) In some control villages, people with disabilities formed their own SHGs. In control villages with SHGs, respondents were chosen in the same manner as in treatment villages. In control villages without SHGs, 20 people were randomly chosen to participate in the survey. There are a total of 1,920 people with disabilities from 96 villages in the sample.

Basic data was collected on each individual in the disabled person's household and in-depth SHG, microloan and economic data was collected on the disabled person chosen to participate in the survey. With this data, I constructed a set of controls composed of non-disabled siblings of disabled respondents. My extract includes those ages 10 years and older because the probability that a child under the age of 10 benefited from a microlending program is minimal. (Note 6) See Table 1 for a summary of the sample design.

Table 1. Sample Design

\begin{tabular}{cc}
\hline Level of division & Number included in sample \\
\hline State & 1 \\
Mandal & 12 \\
Village & $96: 24$ controls, 76 treatment \\
People with disabilities & 1,758 \\
Matched siblings & 565 \\
\hline
\end{tabular}


Two sample selection issues must be addressed to minimize the bias of this analysis. First, the mandals selected to receive interventions were chosen non-randomly. IKP staff chose mandals believed to have both a large number of residents with disabilities and residents with disabilities with substantial interest in forming SHGs. Selecting mandals with a large number of people with disabilities could bias results in either direction. Estimates would be biased upwards if these mandals have unusually highly developed programs for the disabled. Estimates would be biased downwards if the large number of people with disabilities caused each disabled person to receive fewer resources than the average disabled person in Andhra Pradesh. Since mandals with highly motivated disabled residents were assigned to treatment, estimates of IKP's impact would likely be biased upwards. To correct the bias of non-random assignment to treatment, I include non-disabled siblings as a control for disabled respondents and employ a difference-in-differences estimator.

Second, although control villages were not intended to receive treatment, some residents formed SHGs. Including those in control villages who formed SHGs may bias the estimates of the impact of IKP downward. To nullify this bias, I instrument for individual treatment status with an indicator variable for residing in a treatment village. For instrumental variables to resolve the bias caused by two-sided noncompliance, assignment to treatment must increase the odds that a person receives treatment and assignment to control must not increase the odds that a person receives treatment.

\subsection{Descriptive Statistics}

Descriptive statistics for 1,758 people with disabilities and 565 siblings matched on age are shown in Table 2. (Note 7) 37 percent of the disabled in treatment villages and 5 percent of the disabled in control villages participated in SHGs. However, none of the 565 siblings participated in SHGs for the disabled. These findings suggest that the sample satisfies monotonicity and confirms that using instrumental variables will resolve bias from two-sided non-compliance. Other descriptive statistics regarding program and outcome variables can be found in Panel C of Table 2.

Panel A of Table 2 reports the individual characteristics of each sample. T-tests, reported in the third column, reveal the imbalance of the disabled only sample. The disabled only sample in control villages is significantly more likely to be Christian and significantly less likely to be Hindu than the disabled only sample in treatment villages. This is not surprising since one-third of the control villages and none of the treatment villages are located in regions where conversion from Hinduism to Christianity was rigorous. The disabled only sample in treatment villages is significantly more likely to speak Kannadap than the disabled only sample in control villages because one-third of the treatment villages and none of the control villages border Kannada, and most people who speak Kannadap either live in the state of Kannada or in villages that border Kannada. The disabled only sample in control villages is significantly more likely to belong to Scheduled Tribes which reflects the fact that one-third of the control villages is located in Khammam and Khammam "is the largest tribal populated district in Andhra Pradesh" (Maps of India, 2010).

Although differences in region of residence explain some of the imbalances in individual characteristics, regional differences do not explain all of the imbalances. For example, the disabled only sample in treatment villages is significantly more likely to belong to Other Backwards Castes and significantly less likely to speak "other" languages than the same sample in control villages. This is not explained by regional differences and is likely the result of how people with disabilities were identified for inclusion in the sample.

To correct the imbalance in the disabled only sample, I include the matched sibling sample, which is comprised of non-disabled siblings matched on age, as a control. On average, siblings are younger than their disabled counterparts. (Note 8) The matched sibling sample is imbalanced in religion, language, and caste variables. These and other descriptive statistics are reported in Table 2. (Note 9)

Two noteworthy trends arise when comparing those who received treatment in treatment villages to those who received treatment in control villages. First, 40 percent of disabled residents in treatment villages received a loan through IKP, whereas 97 percent of disabled residents of control villages received a loan. Interviews with those who began their own self-help groups (SHGs) in control villages revealed that groups began in villages where local banks expressed a willingness to lend to people with disabilities. These villages also had numerous successful women's SHGs run by IKP staff. These women's groups had strong relationships with the same banking institutions used by SHGs for people with disabilities. Additionally, local IKP staff supported those with disabilities in control villages who began their own SHGs. SHGs started by people with disabilities in control villages shared the following characteristics: (1) they were composed of people desiring loans, (2) they were started in villages where disabled people had equal access to lending institutions, (3) they received support from IKP staff and, (4) in most instances, they were patterned after, and used the same linkages as, successful women's SHGs in the same villages.

Second, 22 percent of those who received treatment in treatment villages and 15 percent of those who received treatment in control villages are on schedule to repay their loans on time. Both of these statistics are low given the percentage of people who received loans. This is suggestive of two phenomena. First, the majority of those who secured loans as a result of the program will not be able to repay the loans on time. Second, those in control villages who 
received loans are less able to repay the loans than their counterparts in treatment villages. This suggests either that those in control villages are more constrained than those in treatment villages or that the SHGs in control villages were not as effective in preparing participants to repay the loans on time as SHGs in treatment villages. (Note 10)

Table 2. Descriptive Statistics for IKP Sample by Village Type

\begin{tabular}{|c|c|c|c|c|c|c|c|c|}
\hline & $\begin{array}{l}\text { Treatment } \\
\text { Villages* }\end{array}$ & $\begin{array}{c}\text { Control } \\
\text { Villages* }\end{array}$ & T Statistic* & $\begin{array}{l}\text { Treatment } \\
\text { Villages** }\end{array}$ & $\begin{array}{c}\text { Control } \\
\text { Villages** }\end{array}$ & $\begin{array}{c}\mathrm{T} \\
\text { Statistic** }\end{array}$ & $\begin{array}{c}\text { Treatment } \\
\text { Villages*** }\end{array}$ & $\begin{array}{c}\text { Control } \\
\text { Villages*** }\end{array}$ \\
\hline \multicolumn{9}{|c|}{ Panel A: Individual Characteristics } \\
\hline Female & $38 \%$ & $42 \%$ & 1.21 & $40 \%$ & $40 \%$ & 0.16 & $35 \%$ & $24 \%$ \\
\hline Age (in years) & 29.3 & 29 & 0.38 & 17.9 & 18.3 & 0.61 & 28.4 & 30.8 \\
\hline Youth & $27 \%$ & $23 \%$ & 1.34 & $70 \%$ & $64 \%$ & 1.09 & $24 \%$ & $14 \%$ \\
\hline Young adult & $24 \%$ & $29 \%$ & 1.24 & $25 \%$ & $32 \%$ & 1.45 & $33 \%$ & $30 \%$ \\
\hline Middle age & $20 \%$ & $25 \%$ & 1.32 & $4 \%$ & $4 \%$ & 0.09 & $19 \%$ & $38 \%$ \\
\hline Elderly & $28 \%$ & $23 \%$ & 1.44 & $1 \%$ & $0 \%$ & 4.49 & $25 \%$ & $18 \%$ \\
\hline Married & $47 \%$ & $48 \%$ & 0.12 & $7 \%$ & $15 \%$ & 1.86 & $45 \%$ & $61 \%$ \\
\hline \multicolumn{9}{|l|}{ Religion (\%) } \\
\hline Hindu & $99 \%$ & $95 \%$ & 3.21 & $99 \%$ & $95 \%$ & 3.46 & $99 \%$ & $100 \%$ \\
\hline Islam & $0 \%$ & $1 \%$ & 1.11 & $0 \%$ & $0 \%$ & 4.48 & $0 \%$ & $0 \%$ \\
\hline Christian & $0 \%$ & $3 \%$ & 3.33 & $0 \%$ & $4 \%$ & 3.21 & $1 \%$ & $0 \%$ \\
\hline Sikh & $0 \%$ & $0 \%$ & 0.63 & $0 \%$ & $1 \%$ & 1.96 & $0 \%$ & $0 \%$ \\
\hline \multicolumn{9}{|l|}{ Language (\%) } \\
\hline Telugu & $84 \%$ & $83 \%$ & 0.13 & $82 \%$ & $75 \%$ & 0.70 & $73 \%$ & $91 \%$ \\
\hline Urdu & $1 \%$ & $1 \%$ & 0.38 & $1 \%$ & $0 \%$ & 1.02 & $2 \%$ & $0 \%$ \\
\hline Hindi & $1 \%$ & $1 \%$ & 0.01 & $0 \%$ & $0 \%$ & 0.72 & $0 \%$ & $0 \%$ \\
\hline Tamil & $0 \%$ & $0 \%$ & 0.81 & $0 \%$ & $0 \%$ & & $0 \%$ & $0 \%$ \\
\hline Kannadap & $13 \%$ & $0 \%$ & 5.41 & $15 \%$ & $0 \%$ & 4.64 & $24 \%$ & $0 \%$ \\
\hline Other & $2 \%$ & $16 \%$ & 4.86 & $2 \%$ & $25 \%$ & 4.71 & $1 \%$ & $9 \%$ \\
\hline \multicolumn{9}{|l|}{ Caste (\%) } \\
\hline General & $16 \%$ & $24 \%$ & 1.61 & $17 \%$ & $27 \%$ & 1.39 & $17 \%$ & $18 \%$ \\
\hline Scheduled Tribe & $4 \%$ & $30 \%$ & 5.95 & $5 \%$ & $36 \%$ & 3.91 & $4 \%$ & $15 \%$ \\
\hline Scheduled Caste & $19 \%$ & $28 \%$ & 1.45 & $16 \%$ & $19 \%$ & 0.52 & $16 \%$ & $37 \%$ \\
\hline \multicolumn{9}{|l|}{ Other Backwards } \\
\hline Caste & $60 \%$ & $15 \%$ & 6.74 & $62 \%$ & $12 \%$ & 5.53 & $62 \%$ & $30 \%$ \\
\hline Other & $1 \%$ & $3 \%$ & 1.83 & $1 \%$ & $6 \%$ & 1.98 & $1 \%$ & $0 \%$ \\
\hline \multicolumn{9}{|c|}{ Panel B: Disability Measures } \\
\hline \multicolumn{9}{|l|}{ Cause } \\
\hline Birth & $60 \%$ & $62 \%$ & 0.67 & -- & -- & -- & $70 \%$ & $67 \%$ \\
\hline Illness & $31 \%$ & $28 \%$ & 0.89 & -- & -- & -- & $22 \%$ & $20 \%$ \\
\hline Injury & $10 \%$ & $10 \%$ & 0.41 & -- & -- & -- & $8 \%$ & $13 \%$ \\
\hline \multicolumn{9}{|l|}{ Type } \\
\hline Multiple & $35 \%$ & $46 \%$ & 2.33 & -- & -- & -- & $32 \%$ & $39 \%$ \\
\hline Sight & $8 \%$ & $10 \%$ & 0.55 & -- & -- & -- & $7 \%$ & $9 \%$ \\
\hline Hearing & $9 \%$ & $7 \%$ & 1.07 & -- & -- & -- & $9 \%$ & $5 \%$ \\
\hline Cognition & $7 \%$ & $12 \%$ & 2.15 & -- & -- & -- & $8 \%$ & $4 \%$ \\
\hline Self Care & $0 \%$ & $0 \%$ & 5.23 & -- & -- & -- & $0 \%$ & $0 \%$ \\
\hline Communication & $3 \%$ & $2 \%$ & 1.68 & -- & -- & -- & $3 \%$ & $0 \%$ \\
\hline Mobility & $38 \%$ & $25 \%$ & 3.39 & -- & -- & -- & $42 \%$ & $44 \%$ \\
\hline \multicolumn{9}{|c|}{ Panel C: Outcome Variables } \\
\hline \multicolumn{9}{|l|}{ Self Help Group } \\
\hline Member & $37 \%$ & $5 \%$ & & $0 \%$ & $0 \%$ & & $100 \%$ & $100 \%$ \\
\hline Received a Loan & $15 \%$ & $5 \%$ & & $0 \%$ & $0 \%$ & & $40 \%$ & $97 \%$ \\
\hline Employed & $53 \%$ & $51 \%$ & & $48 \%$ & $37 \%$ & & $56 \%$ & $67 \%$ \\
\hline Self-Employed & $17 \%$ & $15 \%$ & & $10 \%$ & $6 \%$ & & $24 \%$ & $23 \%$ \\
\hline Attending School & $16 \%$ & $15 \%$ & & $39 \%$ & $51 \%$ & & $14 \%$ & $8 \%$ \\
\hline \multicolumn{9}{|l|}{ Graduated from } \\
\hline Secondary School & $16 \%$ & $16 \%$ & & $32 \%$ & $36 \%$ & & $19 \%$ & $27 \%$ \\
\hline \multicolumn{9}{|l|}{ Imputed Wages } \\
\hline (Rupees) $^{\mathrm{a}}$ & 36.2 & 33.9 & & 25.2 & 22.6 & & 43.0 & 49.5 \\
\hline \multicolumn{9}{|l|}{ Loan Repayment On } \\
\hline Schedule & $8 \%$ & $1 \%$ & & -- & -- & & $22 \%$ & $15 \%$ \\
\hline Number of Observations & 1322 & 436 & & 448 & 117 & & 568 & 50 \\
\hline
\end{tabular}

This table reports descriptive statistics for the disabled only sample, the matched sibling sample and the sample of people who received treatment in each type of village. * Denotes statistics for disabled only sample. ** Denotes statistics for matched sibling sample. *** Denotes statistics for disabled who received treatment. 


\subsection{Comparison of Characteristics of IKP Participants to the National Survey Sample (NSS)}

Since the data for analyzing the IKP program was gathered non-randomly, comparing IKP data to a nationally representative survey of India is instructive. Table 3 compares descriptive statistics of the IKP samples to the NSS $61^{\text {st }}$ Round and reveals a few differences between the NSS sample and the IKP disabled only and disabled + sibling samples. (Note 11) The higher percentage of males in the IKP samples is due, in part, to how people with disabilities were identified for inclusion in the IKP program. Inclusion depended upon being identified as disabled by village residents and men with particular functional limitations are more likely than women to be identified as disabled. Therefore, it is possible that the list enumerating people with disabilities in each village included more men than women (Mont and Sen, 2009). Hence, more men would be recruited to participate as SHG members and non-members.

Table 3. Comparison of Descriptive Statistics for IKP Sample and National Survey Sample 61st Round (2005)

\begin{tabular}{|c|c|c|c|c|c|c|c|c|}
\hline & Female & $\begin{array}{l}\text { Age (in } \\
\text { years) }\end{array}$ & Hindu & Muslim & Christian & Sikh & $\begin{array}{l}\text { Scheduled } \\
\text { Caste }\end{array}$ & $\begin{array}{c}\text { Scheduled } \\
\text { Tribe } \\
\end{array}$ \\
\hline $\begin{array}{l}\text { IKP Disabled } \\
\text { Only Sample }\end{array}$ & $40 \%$ & 27.3 & $98 \%$ & $1 \%$ & $1 \%$ & $0 \%$ & $21 \%$ & $11 \%$ \\
\hline $\begin{array}{l}\text { IKP Disabled + } \\
\text { Sibling Sample }\end{array}$ & $40 \%$ & 25.1 & $98 \%$ & $1 \%$ & $1 \%$ & $0 \%$ & $20 \%$ & $9 \%$ \\
\hline $\begin{array}{l}\text { NSS 61st } \\
\text { Round }\end{array}$ & $49 \%$ & 32.4 & $89 \%$ & $8 \%$ & $3 \%$ & $0 \%$ & $16 \%$ & $7 \%$ \\
\hline
\end{tabular}

Table 3. (continued). Comparison of Descriptive Statistics for IKP Sample and National Survey Sample 61st Round (2005)

\begin{tabular}{|c|c|c|c|c|c|c|c|c|c|}
\hline & Literate & $\begin{array}{c}\text { Literate } \\
\text { males }\end{array}$ & $\begin{array}{l}\text { Literate } \\
\text { females }\end{array}$ & $\begin{array}{c}\text { Below } \\
\text { secondary } \\
\text { education }\end{array}$ & $\begin{array}{c}\text { Secondary } \\
\text { or above }\end{array}$ & Poverty & $\begin{array}{c}\text { Agricultural } \\
\text { sector }\end{array}$ & $\begin{array}{c}\text { Non- } \\
\text { agricultural } \\
\text { sector } \\
\end{array}$ & $\begin{array}{c}\text { Weekly } \\
\text { Income } \\
\text { (Rs.) } \\
\end{array}$ \\
\hline $\begin{array}{l}\text { IKP Disabled } \\
\text { Only Sample }\end{array}$ & $48 \%$ & $53 \%$ & $41 \%$ & $35 \%$ & $19 \%$ & $72 \%$ & $70 \%$ & $30 \%$ & 151.8 \\
\hline $\begin{array}{l}\text { IKP Disabled + } \\
\text { Sibling Sample }\end{array}$ & $54 \%$ & $58 \%$ & $48 \%$ & $36 \%$ & $29 \%$ & -- & $67 \%$ & $33 \%$ & 140.1 \\
\hline $\begin{array}{l}\text { NSS 61st } \\
\text { Round }\end{array}$ & $48 \%$ & $56 \%$ & $39 \%$ & $35 \%$ & $12 \%$ & $62 \%$ & $70 \%$ & $30 \%$ & 106.6 \\
\hline
\end{tabular}

This table reports descriptive statistics for the Disabled Only Sample, the Disabled + Sibling Sample and the NSS. NSS estimates are for the state of Andrah Pradesh. Weekly income for the two IKP samples are imputed from the NSS 61st Round (2005).

Furthermore, the younger age of the disabled only sample is caused by the age limit imposed by IKP administrative staff. Since IKP administrators believed that those over the age of 55 could not benefit from a microlending program, those over the age of 55 were excluded from the IKP program and sample. However, the NSS includes people over the age of 55, thereby increasing the average age of the sample. The disabled only and disabled + sibling samples contain higher percentages of those from Scheduled Castes and Scheduled Tribes. This is most likely explained by the requirement that IKP participants must be below the poverty level; those from Scheduled Castes and Scheduled Tribes are economically more disadvantaged than members of other castes in India. The disabled only sample has a greater percentage of people in poverty than the NSS, which is expected given the goals of the IKP program.

\section{Empirical Strategy}

A natural starting point for analyzing the impact of IKP is an OLS regression of outcome variables on controls and a dummy for program participation. Therefore, I begin with estimates of the following equation:

$$
Y_{v i}=\beta S H G_{v i}+\alpha X_{v i}+\pi_{v}+\varepsilon_{v i}
$$

where $Y_{v i}$ measures outcome variables for person $i$ in village $v, S H G_{v i}$ is an indicator variable equal to one for self help group members, $\pi_{v}$ is a set of village fixed effects and $X_{v i}$ is a vector of personal characteristics. In this model, $\beta$ represents the causal effects of self help group (SHG) membership on outcome variables. Estimates of $\beta$ from equation (1) are unlikely to be informative about the causal effect of SHG membership on various outcomes because 
SHG membership is likely to be endogenous and assignment to treatment was non-random. More precisely, conditional on $X_{v i}$, SHG members may differ causing equation (1) to overestimate some of the impacts of the program while underestimating others. Hence, OLS estimates of the impact of SHG membership on outcomes of interest will be biased. I use two stage least squares to deal with these issues.

The two stage least squares (2SLS) analysis in this paper combines intention-to-treat (ITT) estimation with difference-in-differences (DD) estimation. ITT resolves bias from two-sided non-compliance. The DD estimation uses non-disabled siblings of the disabled as a control group. This strategy compares the difference in the outcomes of the disabled and their non-disabled siblings in treatment and control villages by using the interaction of disability status and village of residence as an instrument for SHG membership. The validity of this approach depends on disability status and village of residence being the only sources of variation.

Disability status and village of residence jointly determine the likelihood of program participation and their interaction is the instrument for all outcome variables. The village of residence dummy captures the differences in outcomes between treatment and control village residents. If the disabled only sample was balanced, the village of residence dummy would suffice as the instrument. Since the disabled only sample is imbalanced, using the village of residence as an instrument would violate the exclusion restriction because the village of residence dummy is likely correlated with other covariates.

Hence, I include the matched sibling sample and interact village of residence with disability status to determine how treatment alters the difference in outcomes between the disabled and their siblings. To be a valid identification strategy, two assumptions must be true. First, more people with disabilities in treatment villages must have received treatment than those with disabilities in control villages and non-disabled siblings in treatment and control villages. Panel $\mathrm{C}$ of Table 2 presents evidence that program participation among the disabled + sibling sample is consistent with monotonicity in assignment to treatment. Second, the difference in outcomes between those with disabilities and non-disabled siblings would have been equivalent in the absence of treatment.

To determine the first stage relationship between SHG membership and the interaction of residing in a treatment village and disability status, I estimate the following equation:

$$
\mathrm{SHG}_{\mathrm{vi}}=\text { disabled }_{\mathrm{vi}}+\eta T_{\mathrm{vi}} * \text { disabled }_{\mathrm{vi}}+\alpha X_{v i}+\pi_{v}+\varepsilon_{v i}
$$

where $S H G_{v i}$ is a dummy variable indicating SHG member status, $T_{v i} *$ disabled $_{v i}$ is an interaction of a treatment village dummy and a disability status dummy, disabled $_{v i}$ is an indicator variable for having a disability, $X_{v i}$ is a vector of personal characteristics and $\pi_{v}$ is a set of village fixed effects. Since the intervention sought to improve various outcomes of the disabled via SHG participation, the first stage must include a dependent variable that encapsulates all of IKP's programmatic goals. The channel by which the program impacted these outcomes was most likely through the total impact of SHG membership, rather than a single component of the SHG program. Therefore, SHG membership is the dependent variable in my first stage. Other studies (Coleman, 1999; Pitt \& Khandker, 1998) have shown that when evaluating microlending programs across different villages, one should assume village-level heterogeneity that convolutes the true impact of the program exists and correct for it. I correct for possible village-level heterogeneity by including village fixed effects.

Subsequently, I estimate three alternative specifications of equation (2). First, to test the effect of including the matched sibling sample on first stage estimates, I estimate equation (2) using the disabled only sample. For this specification, I replace the interaction variable with an indicator for village of residence and remove village fixed effects as well as the disability dummy. Next, I estimate specifications that control for most of the variables IKP staff used to select treatment villages. This is done so that the variation in treatment eligibility remaining is essentially idiosyncratic. To determine the impact of conditioning on assignment to treatment on the first stage, I estimate two alternative specifications of equation (2). I estimate equation (2) using the disabled + sibling sample and replace village fixed effects with fraction of population with a disability. Lastly, I estimate equation (2) using the disabled only sample. For this specification, I replace the interaction variable with a dummy for village of residence, remove the disability dummy and replace village fixed effects with a variable for the fraction of the village's population with a disability and a variable for percent interested in joining SHGs.

Next, I estimate the reduced form relationship between the variable of interest and borrowing, education and labor market outcomes using the following equations:

$$
\begin{gathered}
\mathrm{Y}_{\mathrm{vi}}=\gamma_{\text {disabled }} d_{\mathrm{vi}}+\eta T_{\mathrm{vi}} * \text { disabled }_{\mathrm{vi}}+\alpha X_{v i}+\pi_{v}+\varepsilon_{v i} \\
\mathrm{Y}_{\mathrm{vi}}=\beta T_{\mathrm{vi}}+\alpha X_{v i}+\varepsilon_{v i}
\end{gathered}
$$

where $\mathrm{Y}_{\mathrm{vi}}$ is the outcome of interest, $T_{\mathrm{vi}} *$ disabled $_{\mathrm{vi}}$ is an interaction of a treatment village dummy and a disability status 
dummy, disabled ${ }_{\mathrm{vi}}$ is a dummy for having a disability, $\pi_{v}$ is a set of village fixed effects, $T_{\mathrm{vi}}$ is a dummy for residing in a treatment village and $X_{v i}$ is a vector of personal characteristics. I estimate equation (3a) using the disabled + sibling sample to determine the impact of IKP on all outcomes. $\boldsymbol{\eta}$ indicates the impact of the program on people with disabilities in treatment villages and is the variable of interest.

To determine the effect of conditioning on the assignment mechanisms, I estimate two alternative specifications. First, I estimate equation (3a) for the disabled + sibling sample, replacing village fixed effects with fraction of population with a disability. Second, equation (3b) is estimated for the disabled only sample with the introduction of variables controlling for the fraction of population with a disability and interest in joining SHGs.

Finally, I estimate the following equations by 2SLS:

$$
\begin{gathered}
\mathrm{Y}_{\mathrm{vi}}=\text { rdisabled }_{\mathrm{vi}}+\eta S H G_{\mathrm{vi}}+\alpha X_{v i}+\pi_{v}+\varepsilon_{v i} \\
\mathrm{Y}_{\mathrm{vi}}=\beta S H G_{\mathrm{vi}}+\alpha X_{v i}+\varepsilon_{v i}
\end{gathered}
$$

where the variables are as defined above. I estimate equation (4a) using the disabled + sibling sample. $\eta$ indicates the impact of the program on people with disabilities in treatment villages and is the variable of interest. To test the effect of including the matched sibling sample, I estimate equation (4b) for all outcomes using the disabled only sample.

To be valid, an instrument must be a good predictor of the endogenous variable and cannot be correlated with the error term of the estimating equation. This paper uses the interaction of a village of residence indicator and a disability status indicator as an instrument for self-help group (SHG) membership for equation (4a) and assumes that this interaction is uncorrelated with the error term. Results from the first stage confirm that the interaction of disability status and village of residence is a good predictor of SHG membership. For equation (4b), a treatment village dummy is the instrument for SHG membership.

\section{Results}

\subsection{OLS Estimates}

I start by estimating equation (1). Table 4 presents estimates of equation (1) for borrowing, education and labor market outcomes. I compare the disabled and their non-disabled siblings in treatment and control villages. The OLS estimates suggest that SHG members are more likely to receive a loan, be self-employed, graduate from secondary school and experience higher wages. Conversely, SHG members are less likely to be employed or attending school.

The interpretation of these results as the causal effect of the IKP program relies on the identification assumption that SHG members are identical to SHG non-members. This assumption will be violated if characteristics of SHG members are correlated with assignment to treatment or if the disabled self-selected into treatment. The allocation of the IKP program to each village was a function of mandal-level characteristics, resulting in the violation of the first assumption. However, employing econometric techniques that control for these factors will mitigate the bias from the violation of the above assumption. The next section presents two stage least squares estimates.

\subsection{Two Stage Least Squares Estimates}

Estimates of equation (2) are of intrinsic interest because they provide an assessment of the impact of the IKP program on SHG membership. Additionally, they represent the first stage of a two stage least squares (2SLS) estimation of the impact of IKP on participants.

The results of the first stage, using the disabled + sibling sample, are reported in the first column of Table 5. The estimates confirm that the interaction between the village of residence dummy and the disability status dummy is significantly associated with SHG membership in the expected direction.

A key empirical strategy in this paper is the inclusion of non-disabled siblings as a control. The second column in Table 5 presents estimates of equation (2) using the disabled only sample. Results from this specification show that the estimate of interest decreases from .340 to .259 when siblings are excluded. This indicates that the inclusion of siblings has a sizeable effect on the size of the first stage estimate but does not alter the expected relationship between SHG membership and the variable of interest.

To determine the impact of conditioning on assignment to treatment on the first stage, the third column of Table 5 reports results of an alternative specification of equation (2). The alternative specification replaces village fixed effects with the fraction of village population with a disability. The results show that the estimate of interest is .260. (Note 12) Notable in this table is the finding that the disabled in villages with a larger fraction of people with disabilities are less likely to participate in SHGs, which suggests the assignment mechanism may not have been effective. Also, IKP's effect on SHG membership is remarkably consistent across alternative specifications of the first stage, suggesting estimates from these specifications suffer from the same bias. 
Table 4. OLS Estimates for the Disabled+Sibling Sample

\begin{tabular}{|c|c|c|c|c|c|c|}
\hline & $\begin{array}{r}\text { Received a } \\
\text { loan }\end{array}$ & $\begin{array}{r}\text { Attending } \\
\text { school }\end{array}$ & $\begin{array}{r}\text { Graduated } \\
\text { from } \\
\text { secondary }\end{array}$ & Employed & $\begin{array}{r}\text { Self- } \\
\text { employed }\end{array}$ & $\begin{array}{r}\text { Log } \\
\text { imputed } \\
\text { wages } \\
(\text { Rs. })^{\mathrm{a}} \\
\end{array}$ \\
\hline Self Help Group member & $\begin{array}{l}.454 \text { *** } \\
(.054)\end{array}$ & $\begin{array}{c}. .004 \\
(.021)\end{array}$ & $\begin{array}{l}.065 * * * \\
(.024)\end{array}$ & $\begin{array}{r}-.020 \\
(.027)\end{array}$ & $\begin{array}{r}.048 \\
(.028)\end{array}$ & $\begin{array}{l}.072 * \\
(.036)\end{array}$ \\
\hline Disability dummy & $\begin{array}{l}-.036 * * * \\
(.009)\end{array}$ & $\begin{array}{r}-.038 \\
(.031)\end{array}$ & $\begin{array}{l}-.146 * * * \\
(.035)\end{array}$ & $\begin{array}{l}-.178 * * * \\
(.031)\end{array}$ & $\begin{array}{r}-.049 \\
(.018)\end{array}$ & $\begin{array}{r}-.059 \\
(.037)\end{array}$ \\
\hline Female & $\begin{array}{r}-.006 \\
(.008)\end{array}$ & $\begin{array}{l}-.043 * * \\
(.022)\end{array}$ & $\begin{array}{l}-.119 * * * \\
(.019)\end{array}$ & $\begin{array}{r}-.015 \\
(.028)\end{array}$ & $\begin{array}{r}-.054 \\
(.018)\end{array}$ & $\begin{array}{l}-.260 * * * \\
(.063)\end{array}$ \\
\hline Youth & $\begin{array}{l}-.008 \\
(.020)\end{array}$ & $\begin{array}{l}.465 * * * \\
(.036)\end{array}$ & $\begin{array}{l}.177 * * * \\
(.037)\end{array}$ & $\begin{array}{l}-.320 * * * \\
(.046)\end{array}$ & $\begin{array}{l}-.194 \\
(.040)\end{array}$ & $\begin{array}{l}-.232 * * * \\
(.063)\end{array}$ \\
\hline Young adult & $\begin{array}{r}-.002 \\
(.018)\end{array}$ & $\begin{array}{l}.044 * * \\
(.019)\end{array}$ & $\begin{array}{l}.249 * * * \\
(.033)\end{array}$ & $\begin{array}{r}.035 \\
(.042)\end{array}$ & $\begin{array}{r}-.061 \\
(.037)\end{array}$ & $\begin{array}{r}-.061 \\
(.040)\end{array}$ \\
\hline Middle age & $\begin{array}{r}.014 \\
(.019)\end{array}$ & $\begin{array}{r}.006 \\
(.015)\end{array}$ & $\begin{array}{l}.106 * * * \\
(.028)\end{array}$ & $\begin{array}{l}.067 \text { * } \\
(.039)\end{array}$ & $\begin{array}{l}-.037 \\
(.041)\end{array}$ & $\begin{array}{r}.006 \\
(.034)\end{array}$ \\
\hline Married & $\begin{array}{r}.011 \\
(.013)\end{array}$ & $\begin{array}{l}-.062 * * * \\
(.019)\end{array}$ & $\begin{array}{r}.021 \\
(.024)\end{array}$ & $\begin{array}{l}.278 * * * \\
(.034)\end{array}$ & $\begin{array}{r}.083 \\
(.024)\end{array}$ & $\begin{array}{r}-.020 \\
(.031)\end{array}$ \\
\hline Number of observations & 2323 & 2323 & 2323 & 2323 & 2323 & 960 \\
\hline
\end{tabular}

This table reports OLS estimates of the impact of SHG participation on borrowing, employment and education outcomes. The models include village fixed effects and control for religion, language, and caste. The last column includes the employed disabled + sibling sample, which is a subset of the disabled + sibling sample. All other columns include the disabled + sibling sample. * Indicates significance at the $10 \%$ level. $* *$ Indicates significance at the 5\% level. *** Indicates significance at the $1 \%$ level. ${ }^{\mathrm{a}}$ Imputed wage calcluated from the NSS 61 st Round (2005).

Under the assumptions discussed in section 4, the interaction of village of residence and disability status is available as an instrument for equation (3a). This instrument was shown to be highly correlated with the endogenous variable in the first stage.

Table 5. First Stage Estimates

\begin{tabular}{|c|c|c|c|c|}
\hline \multirow[b]{2}{*}{ Treatment Village $*$ disability } & \multicolumn{4}{|c|}{ SELF HELP GROUP MEMBER } \\
\hline & $\begin{array}{l}.340 \text { *** } \\
(.042)\end{array}$ & -- & $\begin{array}{l}.260 \text { *** } \\
(.040)\end{array}$ & -- \\
\hline Treatment Village dummy & -- & $\begin{array}{l}.259 * * * \\
(.040)\end{array}$ & -- & $\begin{array}{l}.229 * * * \\
(.041)\end{array}$ \\
\hline Disability dummy & $\begin{array}{l}.060 * * \\
(.025)\end{array}$ & -- & $\begin{array}{l}.1144^{* * * *} \\
(.029)\end{array}$ & -- \\
\hline$\%$ of Population with Disability & -- & -- & $\begin{array}{l}-2.501 * \\
(1.461)\end{array}$ & $\begin{array}{l}-3.537 * \\
(1.858)\end{array}$ \\
\hline Interested in SHG & -- & -- & -- & $\begin{array}{l}.247 * * * \\
(.053)\end{array}$ \\
\hline Female & $\begin{array}{r}-.026 \\
(.016)\end{array}$ & $\begin{array}{l}-.044 * \\
(.024)\end{array}$ & $\begin{array}{l}-.034 * \\
(.018)\end{array}$ & $\begin{array}{l}-.047 * * \\
(.023)\end{array}$ \\
\hline Youth & $\begin{array}{r}.031 \\
(.038)\end{array}$ & $\begin{array}{r}.036 \\
(.050)\end{array}$ & $\begin{array}{r}.048 \\
(.043)\end{array}$ & $\begin{array}{r}.014 \\
(.050)\end{array}$ \\
\hline Young adult & $\begin{array}{l}.092 * * * \\
(.033)\end{array}$ & $\begin{array}{l}.132 * * * \\
(.038)\end{array}$ & $\begin{array}{l}.107 \text { *** } \\
(.035)^{2}\end{array}$ & $\begin{array}{l}.111 * * * \\
(.039)\end{array}$ \\
\hline Middle age & $\begin{array}{r}.034 \\
(.032)\end{array}$ & $\begin{array}{r}.053 \\
(.037)\end{array}$ & $\begin{array}{r}.042 \\
(.035)\end{array}$ & $\begin{array}{r}.042 \\
(.037)\end{array}$ \\
\hline Married & $\begin{array}{r}-.001 \\
(.027)\end{array}$ & $\begin{array}{r}.003 \\
(.034)\end{array}$ & $\begin{array}{r}.009 \\
.029)\end{array}$ & $\begin{array}{r}-.008 \\
(.032)\end{array}$ \\
\hline Village fixed effects? & Yes & No & No & No \\
\hline Number of observations & 2323 & 1758 & 2323 & 1758 \\
\hline
\end{tabular}

Results of estimating equation (3a) for borrowing are presented in the first two columns of Tables 6 and the first column of Table 7. Table 6 shows the baseline OLS estimates using the disabled + sibling sample. The estimated impact on borrowing is 8.8 percentage points with the inclusion of religion, language and caste controls. Table 7 reports estimates 
of the reduced form using the disabled only sample and shows that the exclusion of non-disabled siblings slightly increases the estimate for borrowing from .088 to .090. (Note 13)

Table 6. Reduced Form Estimates Using Sibling Controls-Borrowing and Education Outcomes

\begin{tabular}{|c|c|c|c|c|c|c|}
\hline \multirow[b]{2}{*}{ Treatment Village $*$ disability } & \multicolumn{2}{|c|}{ Received a Loan } & \multicolumn{2}{|c|}{ Attending School } & \multicolumn{2}{|c|}{ Graduated from Secondary } \\
\hline & $.079 * * *$ & $.088 * * *$ & $.129 * *$ & $.114 * *$ & .028 & .025 \\
\hline & $(.030)$ & $(.031)$ & $(.059)$ & $(.058)$ & $(.068)$ & $(.074)$ \\
\hline \multirow[t]{2}{*}{ Disability Dummy } & $.050 * *$ & $.041 *$ & $-.137 * * *$ & $-.126 * *$ & $-1.49 * *$ & $-.145 * *$ \\
\hline & $(.022)$ & $(.023)$ & $(.05)$ & $(.049)$ & $(.066)$ & $(.071)$ \\
\hline \multirow[t]{2}{*}{ Female } & -.018 & -.018 & $-.042 *$ & $-.043 *$ & $-1.21 * * *$ & $-.121 * * *$ \\
\hline & $(.010)$ & $(.010)$ & $(.022)$ & $(.022)$ & $(.018)$ & $(.019)$ \\
\hline \multirow[t]{2}{*}{ Youth } & .002 & .006 & $.469 * * *$ & $.464 * * *$ & $.178 * * *$ & $.179 * * *$ \\
\hline & $(.026)$ & $(.026)$ & $(.038)$ & $(.036)$ & $(.04)$ & $(.038)$ \\
\hline \multirow[t]{2}{*}{ Young adult } & $.042 *$ & $.041 *$ & $.045 * *$ & $.043 * *$ & $.252 * * *$ & $.255 * * *$ \\
\hline & $(.023)$ & $(.022)$ & $(.02)$ & $(.019)$ & $(.033)$ & $(.033)$ \\
\hline \multirow[t]{2}{*}{ Middle age } & .029 & .029 & $.005 * * *$ & .007 & $.111 * * *$ & $.108 * * *$ \\
\hline & $(.023)$ & $(.022)$ & $(.014)$ & $(.015)$ & $(.028)$ & $(.028)$ \\
\hline \multirow[t]{2}{*}{ Married } & .011 & .011 & $-.065 * * *$ & $-.064 * * *$ & .018 & .02 \\
\hline & $(.020)$ & $(.019)$ & $(.02)$ & $(.019)$ & $(.026)$ & $(.025)$ \\
\hline \multicolumn{7}{|l|}{ Religion, language } \\
\hline and caste controls? & No & Yes & No & Yes & No & Yes \\
\hline Number of observations & 2323 & 2323 & 2323 & 2323 & 2323 & 2323 \\
\hline
\end{tabular}

Table 7. Reduced Form Estimates for the Disabled Only Sample

\begin{tabular}{|c|c|c|c|c|c|c|}
\hline & $\begin{array}{r}\text { Received a } \\
\text { Loan }\end{array}$ & $\begin{array}{r}\text { Attending } \\
\text { School }\end{array}$ & $\begin{array}{r}\text { Graduated } \\
\text { from } \\
\text { Secondary }\end{array}$ & Employed & $\begin{array}{r}\text { Self- } \\
\text { Employed }\end{array}$ & $\begin{array}{r}\text { Log } \\
\text { Imputed } \\
\text { Wages } \\
(\mathrm{Rs} .)^{\mathrm{a}}\end{array}$ \\
\hline Treatment Village dummy & $\begin{array}{l}.090 \text { *** } \\
(.031)\end{array}$ & $\begin{array}{r}.008 \\
(.014)\end{array}$ & $\begin{array}{r}.012 \\
(.026)\end{array}$ & $\begin{array}{r}.005 \\
(.044)\end{array}$ & $\begin{array}{r}-.011 \\
(.029)\end{array}$ & $\begin{array}{l}.097 \text { *** } \\
(.040)\end{array}$ \\
\hline Female & $\begin{array}{l}-.033 * \\
(.016)\end{array}$ & $\begin{array}{l}-.042 * * \\
(.020)\end{array}$ & $\begin{array}{l}-.103 \text { *** } \\
(.019)\end{array}$ & $\begin{array}{r}-.009 \\
(.027)\end{array}$ & $\begin{array}{l}-.065 \text { *** } \\
(.022)\end{array}$ & $\begin{array}{l}-.266 * * * \\
(.031)\end{array}$ \\
\hline Youth & $\begin{array}{l}-.008 \\
(.037)\end{array}$ & $\begin{array}{l}.458 \text { *** } \\
(.032)\end{array}$ & $\begin{array}{l}.165 \text { *** } \\
(.037)\end{array}$ & $\begin{array}{l}-.311 \text { *** } \\
(.047)\end{array}$ & $\begin{array}{l}-.178 \text { *** } \\
(.038)\end{array}$ & $\begin{array}{l}-.273 * * * \\
(.072)\end{array}$ \\
\hline Young adult & $\begin{array}{l}.061 * * \\
(.026)\end{array}$ & $\begin{array}{l}.034 * * \\
(.014)\end{array}$ & $\begin{array}{l}.235 \text { *** } \\
(.025)\end{array}$ & $\begin{array}{r}.032 \\
(.043)\end{array}$ & $\begin{array}{l}-.071 * \\
(.040)\end{array}$ & $\begin{array}{l}-.042 \\
(.037)\end{array}$ \\
\hline Middle age & $\begin{array}{r}.037 \\
(.027)\end{array}$ & $\begin{array}{r}.003 \\
(.011)\end{array}$ & $\begin{array}{l}.102 \text { *** } \\
(.025)\end{array}$ & $\begin{array}{l}.075 * \\
(.040)\end{array}$ & $\begin{array}{r}-.034 \\
(.041)\end{array}$ & $\begin{array}{l}-.005 \\
(.034)\end{array}$ \\
\hline Married & $\begin{array}{r}.009 \\
(.024)\end{array}$ & $\begin{array}{l}-.061 * * * \\
(.012)\end{array}$ & $\begin{array}{r}.008 \\
(.022)\end{array}$ & $\begin{array}{l}.274 \text { *** } \\
(.035)\end{array}$ & $\begin{array}{l}.096 \text { *** } \\
(.026)\end{array}$ & $\begin{array}{r}.013 \\
(.031)\end{array}$ \\
\hline Number of observations & 1758 & 1758 & 1758 & 1758 & 1758 & 780 \\
\hline
\end{tabular}

This table reports estimates of equation (3b) on borrowing, education and labor market outcomes. All models control for religion, language and caste. The last column includes the employed disabled sample, which is a subset of the disabled only sample. All other columns include the disabled only sample. * Indicates significance at the $10 \%$ level $* *$ Indicates significance at the $5 \%$ level $* * *$ Indicates significance at the $1 \%$ level.

The first column of Table 8 presents 2SLS estimates of equation (4a) for borrowing using the disabled + sibling sample. Religion, language and caste controls are included in the estimation. The point estimate (.280) is substantially higher than the baseline OLS estimate. The point estimate (.346) using the disabled only sample is substantially higher than the 2SLS estimate using the disabled + sibling sample. This suggests that the difference in the first stage estimate between the two samples alters the estimated impact of IKP on borrowing. However, the OLS and 2SLS point estimates from both samples suggest that IKP increased borrowing among the disabled.

Next, I estimate equation (3a) by OLS for the following education outcomes: attending school and graduated from secondary school. The results are presented in Tables 6 and 7. Table 6 shows IKP increased school attendance and 
secondary school graduation by 11.4 percentage points and 2.5 percentage points, respectively. However, IKP's impact on graduating from secondary school is insignificant. Table 7 reports that the exclusion of siblings decreases the value and precision of the estimated impact of IKP on school attendance and graduation rates.

Estimates from specifications excluding the matched sibling sample suggest a smaller effect of IKP on education outcomes than estimates using the disabled + sibling sample. This could be caused by two factors. First, the disabled only sample in control villages are significantly more likely to belong to the general social group than the disabled only sample in treatment villages. The disabled only sample in treatment villages has a significantly greater percentage of members of Other Backwards Caste relative to the same sample in control villages. Since there is substantial difference in school attendance across castes in India, estimates using the disabled only sample will likely yield biased estimates of IKP's impact on education outcomes. Second, since equations run on the disabled only sample exclude village fixed effects, it is plausible that a portion of the bias is due to not controlling for village-level heterogeneity. (Note 14)

The third and fifth columns of Table 8 present 2SLS estimates of equation (4a) for the disabled + sibling sample. The point estimate for attending school (.309) is higher than the OLS estimate as is the point estimate for graduated from secondary school (.109). The 2SLS estimates for the disabled only sample, presented in the fourth and sixth columns, are significantly smaller than the estimates using the disabled + sibling sample.

Results using the disabled + sibling sample suggest that IKP improved school attendance among the disabled, which is noteworthy and leads one to ponder the mechanism through which this operated. Perhaps, increased liquidity enabled the disabled to pay for schooling or enabled them to pay for consumption while in school. Or, perhaps the program increased the empowerment of those with disabilities and caused them to believe they could benefit from an education that might lead to increased occupational opportunities. Long-term data with answers to the above questions would be useful to determine which mechanism was at work.

Also evident from Table 8 is that although IKP had positive and statistically significant effects on borrowing and school attendance, IKP had a larger effect on school attendance. This suggests that the program effects operated through channels other than, or in addition to, microlending. Further study into the precise channel through which IKP affected the school attendance of those with disabilities would be instructive.

Table 8. Two Stage Least Squares Estimates for Borrowing and Education Ourcomes

\begin{tabular}{|c|c|c|c|c|c|c|}
\hline & \multicolumn{2}{|c|}{ Received a Loan } & \multicolumn{2}{|c|}{ Attending School } & \multicolumn{2}{|c|}{ Graduated from Secondary } \\
\hline Self Help Group member & $\begin{array}{l}.280 \text { *** } \\
(.079)\end{array}$ & $\begin{array}{l}.346 \text { *** } \\
(.091)\end{array}$ & $\begin{array}{l}.309 * \\
(.163)\end{array}$ & $\begin{array}{r}.032 \\
(.055)\end{array}$ & $\begin{array}{r}.109 \\
(.206)\end{array}$ & $\begin{array}{r}.046 \\
(.100)\end{array}$ \\
\hline Disability Dummy & $\begin{array}{r}.019 \\
(.019)\end{array}$ & -- & $\begin{array}{l}-.138 * * \\
(.056)\end{array}$ & -- & $\begin{array}{l}-.160 * * \\
(.079)\end{array}$ & -- \\
\hline Female & $\begin{array}{l}-.011 \\
(.009)\end{array}$ & $\begin{array}{l}-.017 \\
(.015)\end{array}$ & $\begin{array}{l}-.035 \\
(.024)\end{array}$ & $\begin{array}{l}-.040 * * \\
(.020)\end{array}$ & $\begin{array}{l}-.118 \text { *** } \\
(.020)\end{array}$ & $\begin{array}{l}-.101 \text { *** } \\
(.018)\end{array}$ \\
\hline Youth & $\begin{array}{r}.003 \\
(.021)\end{array}$ & $\begin{array}{l}-.021 \\
(.030)\end{array}$ & $\begin{array}{l}.454 * * * \\
(.037)\end{array}$ & $\begin{array}{l}.457 \text { *** } \\
(.032)\end{array}$ & $\begin{array}{l}.175 * * * \\
(.039)\end{array}$ & $\begin{array}{l}.163 \text { *** } \\
(.036)\end{array}$ \\
\hline Young adult & $\begin{array}{r}.015 \\
(.020)\end{array}$ & $\begin{array}{r}.015 \\
(.025)\end{array}$ & $\begin{array}{r}.015 \\
(.027)\end{array}$ & $\begin{array}{l}.030 * \\
(.016)\end{array}$ & $\begin{array}{l}.244 * * * \\
(.040)\end{array}$ & $\begin{array}{l}.229 * * * \\
(.026)\end{array}$ \\
\hline Middle age & $\begin{array}{r}.021 \\
(.019)\end{array}$ & $\begin{array}{r}.019 \\
(.024)\end{array}$ & $\begin{array}{r}-.003 \\
(.017)\end{array}$ & $\begin{array}{r}.001 \\
(.010)\end{array}$ & $\begin{array}{l}.105 \text { *** } \\
(.027)\end{array}$ & $\begin{array}{l}.100 \text { *** } \\
(.025)\end{array}$ \\
\hline Married & $\begin{array}{r}.011 \\
(.015)\end{array}$ & $\begin{array}{r}.008 \\
(.017)\end{array}$ & $\begin{array}{l}-.063 * * * \\
(.020)\end{array}$ & $\begin{array}{l}-.061 \text { *** } \\
(.012)\end{array}$ & $\begin{array}{r}.020 \\
(.025)\end{array}$ & $\begin{array}{r}.007 \\
(.022)\end{array}$ \\
\hline Village fixed effects? & Yes & No & Yes & No & Yes & No \\
\hline Number of observations & 2323 & 1758 & 2323 & 1758 & 2323 & 1758 \\
\hline
\end{tabular}

This table reports 2SLS estimates of the impact of self help group participation on borrowing and education outcomes. The first. third and fifth columns include the disabled + sibling sample while the second, fourth and sixth columns include the disabled only sample. For the odd columns, Treatment Village * disability dummy instruments SHG membership. For the even columns, Treatment Village dummy instruments for SHG membership. All models include religion, language and caste controls. * Indicates significance at the $10 \%$ level. ** Indicates significance at the 5\% level. *** Indicates significance at the $1 \%$ level.

Turning to labor market outcomes, I estimate equation (3a) for employment and wages. Results are presented in the last three columns of Table 7 and in Table 9. Estimates of the impact of IKP on log imputed wage are determined for the sample of those who reported being employed in a wage or salary position. Table 9 reports OLS estimates using the disabled + sibling sample. The estimated impact of IKP on employment, self-employment and log imputed wages are -8.1 percentage points, -6.2 percentage points and -12.8 percentage points, respectively. All estimates are insignificant.

Table 7 reports that the exclusion of siblings causes the reduced form estimates of the program's impact on 
employment and log imputed wage to become positive and attenuates the estimate for self-employment. The estimate for log imputed wage becomes significant. Including the matched sibling sample causes the estimates of the variable of interest for all labor market outcomes to decrease.

Table 10 presents 2 SLS estimates of equations (4a) and (4b) for employment and wages. The point estimate for employment (-.157) is lower than the OLS estimate as are the point estimates self-employment (-.117) and log imputed wages (-.152), which continues the trend of 2SLS estimates suggesting a larger impact of the program than OLS estimates. Notably, the 2SLS estimate of IKP's impact on log imputed wages becomes positive and significant when using the disabled only sample. (Note 15)

The results of the 2SLS estimation using the disabled + sibling sample reinforce the finding that the program had an insignificant impact on the labor market outcomes of those with disabilities in treatment villages. Given the findings from the baseline specification that IKP did not affect labor market participation or wages, it is somewhat surprising that all of the alternative specifications suggest nearly identical positive and significant impacts of IKP on wages. This suggests that among those with disabilities, treatment village residents earn more. However, since the alternative specifications exclude village fixed effects and conditioning on the assignment mechanism does not control for village-level heterogeneity, it is likely that the results are biased. For example, treatment villages may have a higher fraction of high-paying jobs, which would cause people with disabilities in treatment villages to have greater access to high-paying employment, thereby causing the disabled in treatment villages to have higher average earnings. (Note 16) It is likely that the village fixed effects in the baseline specification control for this heterogeneity.

Table 9. Reduced Form Estimates Using Sibling Controls—Labor Market Outcomes

\begin{tabular}{lcccccc}
\hline & \multicolumn{2}{c}{ Employed } & \multicolumn{2}{c}{ Self-Employed } & \multicolumn{2}{c}{ Log Imputed Wage (Rs. $)^{\text {a }}$} \\
\hline Treatment Village * disability & -.099 & -.081 & -.054 & -.062 & -.121 & -.128 \\
& $(.070)$ & $(.069)$ & $(.038)$ & $(.040)$ & $(.086)$ & $(.086)$ \\
Disability Dummy & $-.105 *$ & $-.122 * *$ & .005 & .013 & .056 & .066 \\
& $(.058)$ & $(.057)$ & $(.031)$ & $(.034)$ & $(.067)$ & $(.066)$ \\
Female & -.009 & -.014 & $-.058 * * *$ & $-.055 * * *$ & $-.280 * * *$ & $-.266 * * *$ \\
& $(.028)$ & $(.027)$ & $(.018)$ & $(.018)$ & $(.038)$ & $(.036)$ \\
Youth & $-.329 * * *$ & $-.320 * * *$ & $-.189 * * *$ & $-.192 * * *$ & $-.217 * * *$ & $-.222 * * *$ \\
& $(.047)$ & $(.046)$ & $(.039)$ & $(.039)$ & $(.071)$ & $(.065)$ \\
Young adult & .034 & .033 & -.051 & -.056 & -.044 & -.051 \\
& $(.041)$ & $(.041)$ & $(.037)$ & $(.037)$ & $(.041)$ & $(.041)$ \\
Middle age & $.066 *$ & $.066 *$ & -.041 & -.036 & .005 & .010 \\
& $(.038)$ & $(.039)$ & $(.041)$ & $(.041)$ & $(.036)$ & $(.035)$ \\
Married & $.278 * * *$ & $.279 * * *$ & $.087 * * *$ & $.085 * * *$ & -.002 & -.016 \\
& $(.036)$ & $(.034)$ & $(.024)$ & $(.024)$ & $(.030)$ & $(.033)$ \\
Religion, language & & & & & & No \\
and caste controls? & No & Yes & No & Yes & & Yes \\
Number of observations & 2323 & 2323 & 2323 & 2323 & 960 & 960 \\
\hline
\end{tabular}

This table reports reduced form estimates of equation (3a) for labor market outcomes for the disabled + sibling sample. All models include village fixed effects. The first two columns include the disabled + sibling sample whereas third column includes the employed disabled + sibling sample. * Indicates significance at the $10 \%$ level. ** Indicates significance at the 5\% level. *** Indicates significance at the $1 \%$ level. ${ }^{a}$ Imputed wage calcluated from the NSS 61st Round (2005).

The insignificant impact of IKP on the short-run employment outcomes of the disabled is expected because the IKP program significantly increased school attendance among those with disabilities. Since those in the IKP program are more likely to be attending school, and assuming that education acquisition and labor market participation are ordered and linear (i.e. one cannot work until literate), the findings regarding labor market participation are consistent with improved education outcomes. Perhaps increased school attendance among the disabled will enable those with disabilities to engage in income-generating activities in the long run. An area for future research is determining the long-term labor market outcomes of IKP participants.

\section{Conclusion}

The IKP disability interventions led to an increase in self help group participation, improved borrowing and education outcomes, and did not impact labor market participation among the disabled. The estimates of the effect of the program on the borrowing of people with disabilities range from .08 to .28 and the program's estimated effect on school attendance ranges from .114 to .309 . However, these improvements were not accompanied by improved labor market outcomes. 
Table 10. Two Stage Least Squares Estimates for Labor Market Outcomes

\begin{tabular}{|c|c|c|c|c|c|c|}
\hline \multirow[b]{2}{*}{ Self Help Group member } & \multicolumn{2}{|c|}{ Employed } & \multicolumn{2}{|c|}{ Self-Employed } & \multicolumn{2}{|c|}{ Log Imputed Wages(Rs. $)^{\mathrm{a}}$} \\
\hline & -.157 & .019 & -.117 & -.042 & -.152 & $.303 * *$ \\
\hline & $(.205)$ & $(.170)$ & $(.122)$ & $(.114)$ & $(.223)$ & $(.122)$ \\
\hline \multirow[t]{2}{*}{ Disability Dummy } & $-.133 *$ & -- & .004 & -- & .044 & -- \\
\hline & $(.069)$ & & $(.041)$ & & $(.094)$ & \\
\hline \multirow[t]{2}{*}{ Female } & -.019 & -.008 & $-.058 * * *$ & $-.067 * * *$ & $-.277 * * *$ & $-.245 * * *$ \\
\hline & $(.028)$ & $(.027)$ & $(.019)$ & $(.023)$ & $(.043)$ & $(.034)$ \\
\hline \multirow[t]{2}{*}{ Youth } & $-.316 * * *$ & $-.311 * * *$ & $-.189 * * *$ & $-.176 * * *$ & $-.209 * * *$ & $-.310 * * *$ \\
\hline & $(.046)$ & $(.048)$ & $(.040)$ & $(.039)$ & $(.075)$ & $(.078)$ \\
\hline \multirow[t]{2}{*}{ Young adult } & .046 & .030 & -.047 & -.065 & -.035 & $-.095 * *$ \\
\hline & $(.045)$ & $(.049)$ & $(.038)$ & $(.042)$ & $(.052)$ & $(.045)$ \\
\hline \multirow[t]{2}{*}{ Middle age } & $.070 *$ & $.074 *$ & -.033 & -.032 & .018 & -.036 \\
\hline & $(.040)$ & $(.042)$ & $(.041)$ & $(.041)$ & $(.038)$ & $(.038)$ \\
\hline \multirow[t]{2}{*}{ Married } & $.277 * * *$ & $.274 * * *$ & $.083 * * *$ & $.096 * * *$ & -.023 & .011 \\
\hline & $(.035)$ & $(.035)$ & $(.025)$ & $(.026)$ & $(.033)$ & $(.034)$ \\
\hline Village fixed effects? & Yes & No & Yes & No & Yes & No \\
\hline Number of observations & 2323 & 1758 & 2323 & 1758 & 960 & 780 \\
\hline
\end{tabular}

This table reports 2SLS estimates of the impact of IKP membership on labor market outcomes. The first and third columns include the disabled + sibling sample. The fifth column includes the employed disabled + sibling sample. The second and fourth columns include the disabled only sample while the sixth column includes the employed disabled only sample. In the first, third and fifth columns, Treatment Village * disability dummy instruments for SHG membership. In the second, fourth and sixth columns, Treatment Village dummy instruments for self help group membership. All specifications include religion, language and caste controls. * Indicates significance at the $10 \%$ level. ** Indicates significance at the 5\% level. *** Indicates significance at the $1 \%$ level. ${ }^{a}$ Imputed wage calculated from the NSS 61st Round (2005).

Three alternative specifications to the baseline estimations were proposed and executed. The first alternative estimation, which excluded non-disabled siblings, yielded estimates similar to the baseline estimation for borrowing. However, results from estimations excluding siblings suggest IKP did not impact education or labor market outcomes. The second alternative, which replaced village fixed effects with fraction of population with disability, and third alternative, which replaced village fixed effects with fraction of population with disability and interest in joining self help groups, yielded results similar to the first alternative specification.

While the outcomes of IKP disability interventions studied in this paper suggest the program did impact those with disabilities, the long-term economic well-being of IKP participants is unclear. As alluded to in the previous section, most of the people who secured loans through IKP are not on schedule to repay their loans on time. If, by virtue of their participation in IKP, the disabled smooth short-term consumption but experience greater debt, it is plausible that their participation in IKP may not improve their long-term well-being. Additionally, understanding the future labor market outcomes of current IKP participants who enrolled in school as a result of the IKP program would be of interest in determining the long-term well-being of IKP participants. If IKP participants experience greater future labor market participation and increased wages due to their participation in IKP, the program may have laid the foundation for improved economic well-being among people with disabilities.

\section{Acknowledgements}

I am deeply grateful to David Autor, Joshua Angrist, Esther Duflo and David Wittenburg for their excellent guidance and support. I thank the Disability and Development Team of The World Bank for providing access to the data for this paper. I also thank MIT's Labor Lunch attendees for their helpful feedback and suggestions. I thank Sage Jankowitz and Michael Julius Motta, Jr. for their excellent research assistance. Financial support from the National Science Foundation and the National Bureau of Economic Research is gratefully acknowledged.

\section{References}

Banerjee, A., Duflo, E., Glennerster, R., \& Kinnan, C. (2013). The Miracle of Microfinance? Evidence from a Randomized Evaluation. NBER Working Paper. http://www.nber.org/papers/w18950

Coleman, B. (1999). The Impact of Group Lending in Northeast Thailand. Journal of Development Economics, 60(1), 105-141. http://dx.doi.org/10.1016/S0304-3878(99)00038-3

Maps of India. (2010). Khammam District Map. http://www.mapsofindia.com/maps/andhrapradesh/districts/khammam.htm

Copestake, J., Bhalotra, S., \& Johnson, S. (2001). Assessing the Impact of Microcredit: a Zambian Case Study. 
Journal of Development Studies, 37(4), 81-100. http://dx.doi.org/10.1080/00220380412331322051

Copestake, J., Dawson, P., Fanning, J. P., McKay, A., \& Wright-Revolledo, K. (2005). Monitoring the Diversity of the Poverty Outreach and Impact of Microfinance: a Comparison of Methods Using Data from Peru. Development Policy Review, 23(6), 703-723. http://dx.doi.org/10.1111/j.1467-7679.2005.00309.x

DFID. (2000). Disability, Poverty and Development. (Unpublished). Social Development Department. International Labour Office. (2006). Occupational Safety and Health: Synergies Between Security and Productivity. Geneva: International Labour Office. http://www.ilo.org/public/english/standards/relm/gb/docs/gb295/pdf/esp-3.pdf.

Jeffrey, R., \& Singal, N. (2009). Transitions to Adulthood for Young People with Disabilities in India: Current Status and Emerging Prospects. Asia Pacific Disability Rehabilitation Journal, 20, 15-40.

MkNelly, B., \& Lippold, K. (1998). Practitioner-Led Impact Assessment: a Test in Mali. AIMS Paper. (Unpublished). Freedom from Hunger and Management Systems International.

Mont, D., \& Sen, S. (2009). (Unpublished). Preliminary Findings from an Assessment of the Indira Kranthi Pratham Program for Persons with Disabilities.

Morduch, J. (1998). Does microfinance really help the poor?: New evidence from flagship programs in Bangladesh. Research Program in Development Studies, Woodrow School of Public and International Affairs. http://www.nyu.edu/projects/morduch/documents/1998-Does-MF-really-help-the-poor.pdf

NSSO. (2005). Disabled Persons in India, NSS $61^{\text {st }}$ round. National Sample Survey Organisation: New Delhi.

ORG Center for Social Research. (2008). Study SHG and Government Programs for People with Disabilities in Andhra Pradesh. (Unpublished).

Osmani, L. (2007). A Breakthrough in Women's Bargaining Power: the Impact of Microcredit. Journal of International Development, 19(5), 695-716. http://dx.doi.org/10.1002/jid.1356

Pitt, M., \& Khandker, S. (1998). The Impact of Group-Based Credit Programs on Poor Households in Bangladesh: Does the Gender of Participants Matter? Journal of Political Economy, 106(5), 958-996.

Registrar General of India. (2001). Census of India. Retrieved from: http://www.censusindia.net

Tedeschi, G. (2008). Overcoming Selection Bias in Microcredit Impact Assessments: A Case Study in Peru. Journal of Development Studies, 44(4), 504-518. http://dx.doi.org/10.1080/00220380801980822

The World Bank. (2007). People with Disabilities in India: From Commitments to Outcomes. New Delhi: The World Bank.

\section{Notes}

Note 1. The Government of India and private entities have undertaken the following initiatives to improve the labor market outcomes of the disabled: quotas for employment in the public sector, Employment Exchanges, microlending, Vocational Rehabilitation Centers and Non-Governmental Organizations Initiatives. However, these initiatives have had relatively little success in improving labor market outcomes of the disabled in rural areas due to factors such as inadequate funding, minimal attention to job retention and placement of service centers primarily in urban areas.

Note 2. Mandals are subdivisions of states in India. See Figure A1 in Appendix A for a diagram of the geographical divisions of India.

Note 3. Andhra Pradesh has a total of 1,109 mandals. All mandals not assigned to treatment were considered controls.

Note 4. Staff of The World Bank decided to include 20 respondents per village as a result of the following calculations. The 2001 Census of India reports the population of rural Andhra Pradesh to be 53,331,546 which is distributed across 26,613 villages. This yields an average population of 2,004 people per village. Assuming a disability rate of 1.86 percent, 37 people with disabilities would reside in each village. IKP staff believed including 20 disabled people from each village in the sample would yield a representative sample of people with disabilities from each village.

Note 5. If fewer than 10 IKP participants resided in a village, all were selected to be surveyed. The rest of the 20 people sampled were chosen randomly from those with disabilities who did not participate in IKP.

Note 6. Contact author for a description of the variable coding procedure used.

Note 7. To be included in the sample, non-disabled siblings must be up to 5 years younger or 5 years older than their disabled siblings.

Note 8. Non-disabled siblings are younger because non-disabled siblings included in this survey must reside in the same household as their disabled sibling. On average, the younger the disabled person is the more likely he lives in a household with his non-disabled siblings. 
Note 9. Panels B and C do not have entries for the matched sibling sample for some variables because siblings did not answer the part of the survey corresponding to these variables.

Note 10. SHG members were supposed to prepare a Micro Credit Plan, which would detail the plan for loan repayment. These plans were intended to insure that borrowers would be able to repay their loans on time. However, the data suggests that less than 20 percent of SHGs required members to prepare the plans.

Note 11 . The disabled + sibling sample combines the disabled only sample and the matched sibling sample.

Note 12. The fourth column reports estimates of equation (2) which replaces village fixed effects with fraction of village population with a disability and a dummy for interest in joining a SHG. The estimated impact of IKP from this estimation is similar to the other specifications.

Note 13. I also estimated the program's impact on borrowing by conditioning on the assignment mechanism and found that conditioning on assignment to treatment does not substantively alter the findings from the baseline estimation. This suggests that estimates of IKP's impact on borrowing behavior derived from the alternative specifications are unbiased.

Note 14. Interestingly, estimates using the disabled only sample are similar to estimates using the disabled + sibling sample that replace village fixed effects with fraction of population with disability. Since estimates of IKP's effect on education from specifications replacing village fixed effects with fraction of population with a disability yields estimates similar to the disabled only specification, it is likely that the variable, fraction of population with a disability, does not adequately control for some village-level characteristics.

Note 15. IKP's estimated impacts on labor market outcomes for the disabled only sample are presented in the second, fourth and sixth columns of Table 10 .

Note 16. Within the disabled only sample, a greater percentage of those residing in treatment villages are employed in the non-agricultural sector than those in control villages. Those employed in the agricultural sector tend to earn lower wages than those employed in the non-agricultural sector.

\section{Appendix A}

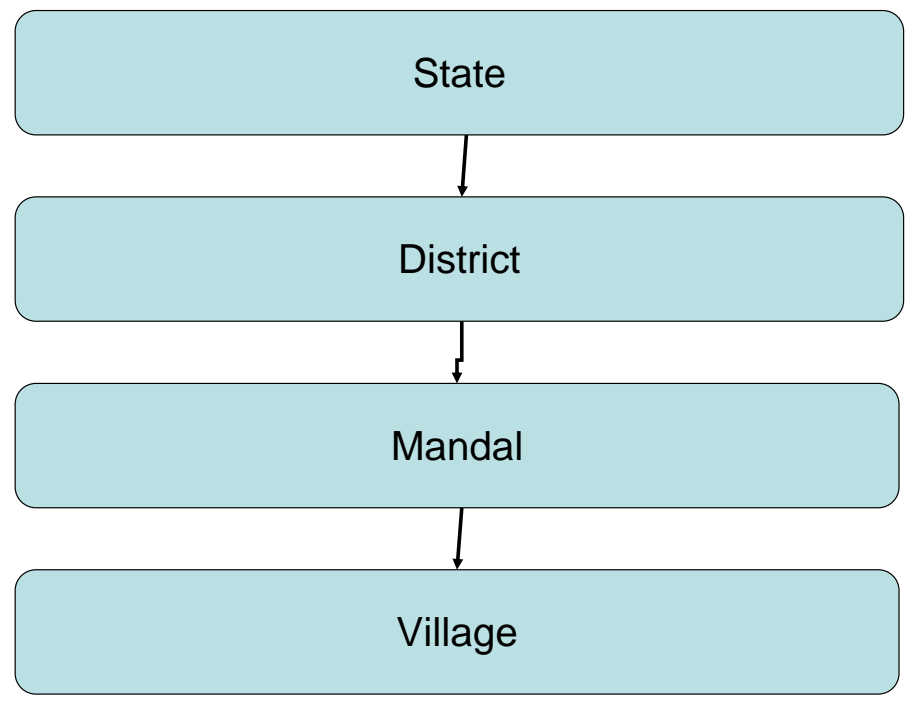

Figure A1 Geographical Divisions of India

\section{(cc) EY}

This work is licensed under a Creative Commons Attribution 3.0 License. 